\title{
[4+2]-Cycloaddition Of Sterically Hindered Thiophene S-Oxides To Alkenes And So Extrusion Reactions Of The Cycloadducts
}

\author{
Thies Thiemann, Jesus Iniesta \& David J. Walton
}

To cite this article: Thies Thiemann, Jesus Iniesta \& David J. Walton (2016): [4+2]-Cycloaddition Of Sterically Hindered Thiophene S-Oxides To Alkenes And So Extrusion Reactions Of The Cycloadducts, Phosphorus, Sulfur, and Silicon and the Related Elements, DOI: 10.1080/10426507.2015.1100191

To link to this article: http://dx.doi.org/10.1080/10426507.2015.1100191

Accepted author version posted online: 20

Jan 2016.

Submit your article to this journal $\llbracket$

Џ Article views: 10

View related articles $\sqsubset$

View Crossmark data $\nearrow$ 


\title{
ACCEPTED MANUSCRIPT
}

[4+2]-CYCLOADDITION OF STERICALLY HINDERED THIOPHENE S-OXIDES TO ALKENES AND SO EXTRUSION REACTIONS OF THE CYCLOADDUCTS

Thies Thiemann $^{\mathrm{a}, *, \#, \text { Jesus Iniesta }}{ }^{\mathrm{b}, \mathrm{c}}$, David J. Walton ${ }^{\mathrm{d}}$

${ }^{a}$ Institute of Materials Chemistry, Kyushu University, Kasuga-koh-en, Kasuga-shi 816-8580, Japan

${ }^{\mathrm{b}}$ Institute of Electrochemistry, University of Alicante, 03690, San Vicente del Raspeig, Alicante, Spain

'Physical Chemistry Department, University of Alicante, 03690, San Vicente del Raspeig, Alicante, Spain

${ }^{\mathrm{d}}$ School of Health and Life Sciences, Coventry University, Priory Street, Coventry, CV1 5FB, UK

\#current address: Department of Chemistry, United Arab Emirates University, PO Box 15551, Al Ain, Abu Dhabi, United Arab Emirates; thies@uaeu.ac.ae; thiesthiemann@yahoo.de

*Corresponding Author Email: thiesthiemann@yahoo.de

\begin{abstract}
Cycloaddition reactions of 2,5-di-tert-butylthiophene $S$-oxide and 2,3,4,5-tetrakis $(p$ tolyl)thiophene $S$-oxide with alkenes are described. The reactivity of 2,5-di-tert-butylthiophene $S$-oxide as diene in Diels Alder reactions is compared with 2,5-di-tert-butylthiophene $S, S$-dioxide. The thermal and photochemical SO extrusion reactions of the cycloadducts under formation of
\end{abstract}




\section{ACCEPTED MANUSCRIPT}

highly substituted aromatic compounds are exemplified.

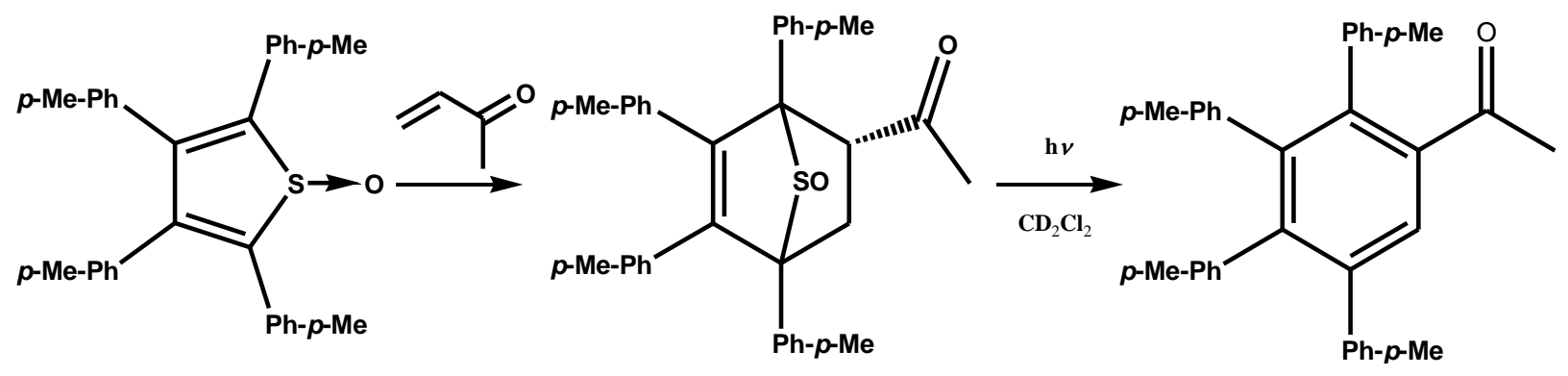

\section{Keywords}

thiophene $S, S$-dioxide, thiophene $S$-oxide, cycloaddition, SO extrusion 


\section{ACCEPTED MANUSCRIPT}

\section{INTRODUCTION}

Easy synthetic access to arenes with neighboring sterically exacting substituents is still of great interest. ${ }^{1}$ One preparative route to arenes is via [4+2]-cycloaddition and subsequent oxidative aromatization. ${ }^{2}$ For a more facile approach to substituted arenes via [4+2]cycloaddition, it is advisable to introduce at least two double bonds into the constructed ring system during the cycloaddition. This can be achieved by the right selection of the dienophile in form of an acetylene,,$^{2,3}$ an allene ${ }^{4}$ or an aryne ${ }^{5}$ in case of an areno-annelation reaction. Alternatively, the additional unsaturation can be introduced by choosing a cyclic dienophile, which would lead to a bicyclic system with a bridged 6-membered carbocycle, where the bridge would be extruded or opened in a subsequent reaction step, which simultaneously introduces the additional unsaturation into the carbocycle. Use of a cyclic diene has the advantage of a lockedin cisoid diene system, ideal for the cycloaddition. Typical examples of such cyclic dienes that lead to bicyclic cycloadducts with an extrusable bridge are pyrones, ${ }^{6}$ cyclopentadienones, ${ }^{7}$ furans $^{8}$ and thiophenes ${ }^{9}$ and their derivatives. While furans, especially those with electrondonating substituents, are passable dienes for Diels-Alder type cycloadditions, thiophenes are not, where in fact only a handful of specifically substituted thiophenes ${ }^{9}$ have been used successfully. Thiophenes, however, can be oxidized to thiophene oxides, and these are classical cyclic dienes. Thiophene $S, S$-dioxides ${ }^{10}$ have been used as diene components in cycloaddition reactions for some time, while the preparation of thiophene $S$-oxides and their use as substrates in cycloaddition reactions have been studied more recently. ${ }^{11,12}$ For the most part, thiophene $S, S$ dioxides are thermally and photochemically ${ }^{13}$ much more stable than thiophene $S$-oxides. On the other hand, as dienes in Diels Alder type reactions, thiophene $S$-oxides have been found 


\section{ACCEPTED MANUSCRIPT}

generally more reactive than the corresponding thiophene $S, S$-dioxides. In the following, the authors show the reactivity of a tetraarylthiophene $S$-oxide and of 2,5-tert-butylthiophene $S$ oxide as diene components in Diels Alder reactions with alkenes. As contrast, comparative cycloadditions with tetraphenylcyclopentadienone (tetracyclone) and with 2,5-di-tertbutylthiophene $S, S$-dioxide are shown. Also, photochemically and thermally driven transformations of the 7-thia-bicyclo[2.2.1] hept-5-ene $S$-oxides as the primary cycloadducts to the corresponding substituted arenes and cyclohexadienes are exemplified. Overall, the cycloaddition of alkenes to thiophene $S$-oxides with bulky substituents at positions C2 and C5 with a subsequent SO-extrusion reaction is to be seen as an additional route to oligo-substituted arenes with bulky neighboring groups.

\section{RESULTS AND DISCUSSION}

First was tested the reactivity of alkenes towards tetrakis(p-tolyl)thiophene $S$-oxide (1a), which was synthesized via reaction of thionyl chloride with tetrakis $(p$ tolyl)zirconacyclopentadiene, produced from bis(cyclopentadienyl)zirconium(IV) dichloride and bis( $p$-tolyl)acetylene, following an analogous procedure. ${ }^{4,9,14}$ It must be noted that the

cycloaddition of tetraarylthiophene $S$-oxides with alkynes has been studied previously, ${ }^{4,15}$ but not with alkenes. Here, tetrakis( $p$-tolyl)thiophene $S$-oxide (1a) was reacted with a number of dienophiles in $\mathrm{CHCl}_{3}$ (Scheme 1). To many of the dienophiles with two or one electron withdrawing group, tetrakis(p-tolyl)thiophene $S$-oxide (1a) already cycloadds at $50{ }^{\circ} \mathrm{C}$ in acceptable yields, although tetrakis( $p$-tolyl)thiophene $S$-oxide (1a) does not react well with $(E)$ 1,2-dibenzoylethene (2f) at $50^{\circ} \mathrm{C}$, so that the reaction temperature in this case had to be raised to 


\section{ACCEPTED MANUSCRIPT}

$70{ }^{\circ} \mathrm{C}$. Even then, the yield of the cycloadduct $\mathbf{3 g}$ remained poor. 1a itself is thermally relatively stable, although thiophene $S$-oxides are generally known to be thermally relatively labile. When heated to $70^{\circ} \mathrm{C}$ in chloroform for $11 \mathrm{~h}, \mathbf{1 a}$ was recovered unchanged. With maleic anhydride (2b) and $N$-phenylmaleimide $(\mathbf{2 a})$ at $50{ }^{\circ} \mathrm{C}, \mathbf{1 a}$ gave the corresponding cycloadducts $\mathbf{3 a}$ and $\mathbf{3 b}$ in excellent yield. $\mathbf{3 b}$ was hydrolyzed to the diacid 3c $\left(\mathrm{BzlNMe}_{3} \mathrm{OH}, \mathrm{H}_{2} \mathrm{O}\right),{ }^{16}$ which was subsequently converted with an ethereal solution of diazomethane to diester $\mathbf{3 d}$, which was also produced directly in a cycloaddition of $\mathbf{1 a}$ with dimethyl maleate (2c) (Scheme 1).

In all cycloaddition reactions above, the products were formed as one stereoisomer, only. This stereoselectivity has been remarked upon previously in analogous reactions, where the stereochemistry of the cycloadducts could be determined by single crystal X-ray structure analysis. ${ }^{17}$ The reactions show endo-selectivity, indicating kinetic control of the product, with the lone electron pair on sulfur of the sulfoxy-bridge lying on the side of the newly formed double bond of the product. The stereoselectivity at sulfur is governed by the Cieplak effect. ${ }^{18}$ Experimental observations in Diels-Alder reactions of dienophiles with 5-substituted cyclopentadienes have shown that the dienophiles will approach anti to the antiperiplanar $\sigma$-bond that is the better donor at the 5-position of the cyclopentadiene. The lone-pair electron orbital on sulfur stabilizes the vacant $\sigma^{*}$-orbital of the developing incipient $\sigma$-bonds better than the lonepair electron orbitals of the oxygen of the sulfoxy moiety.

When comparing tetraarylthiophene $S$-oxides with tetraarylcyclopentadienones (tetracyclones) as dienes in cycloaddition reactions, it must be noted that tetracyclones for the most part necessitate higher reaction temperatures than their tetraarylthiophene $S$-oxide counterparts. When stirring a 


\section{ACCEPTED MANUSCRIPT}

mixture of tetraphenylthiophene $S$-oxide (1b), tetraphenylcyclopentadienone (4a) (or tetrakis-ptolylthiophene-S-oxide (1a) and 3,4-bis(p-tolyl)-2,5-diphenylcyclopentadienone (4b) and $N$ phenylmaleimide (2a) in deuterated chloroform, only the cycloadduct 3i (and 3a, respectively) of the tetraarylthiophene $S$-oxide with $N$-phenylmaleimide was obtained (Scheme 2).

Tetracyclones are usually thermally much more stable than tetraarylthiophene-S-oxides. Nevertheless, tetracyclones are not stable at elevated temperatures under all conditions. Thus, the authors have shown that tetracyclones convert to $\alpha$-pyrones when heated in aerated diphenyl ether, ${ }^{19}$ a solvent that is frequently used as a solvent for Diels-Alder type cycloaddition reactions at higher temperatures. Also, tetracyclones have been shown to be reductants at elevated temperatures, such as in the case of the cycloaddition of tetraphenylcyclopentadienone to benzothiophene-S,S-dioxide, where excess tetraphenylcyclopentadienone reduces the sulfone moiety in the cycloadduct, in juxtaposition to the same reaction with tetraphenylthiophene $S$-oxide, where the sulfone moiety in the cycloadduct remains intact. ${ }^{20}$ Nevertheless, cycloaddition reactions of tetracyclones under microwave irradiation ${ }^{21}$ and under solvent free conditions ${ }^{7 \mathrm{c}}$ have recently provided additional possibilities of preparing oligoarylbenzenes under milder conditions. Therefore, tetraarylthiophene $S$-oxides and tetracyclones can be seen as complimentary diene substrates for the preparation of oligoarylbenzenes and of generally oligosubstituted benzenes, complimentary also, as the strategy of preparation differs and, depending on the substitution, one or the other preparation may be preferred due to ease of access. Tetraarylcyclopentadienones can be prepared by Weiss reaction, which for instance would not allow an easy preparation of tetracyclones with four different aryl groups. Also, alkyl-substituted cyclopentadienones are not

easily accessible ${ }^{22}$ and often react as dienophile rather than as diene. ${ }^{23}$ The preparation of 


\section{ACCEPTED MANUSCRIPT}

thiophene $S$-oxides by oxidation of the corresponding thiophenes limits the substitution pattern of the thiophene $S$-oxides to the substitution pattern of the corresponding thiophenes, where it must be ascertained that the substituents still allow for a smooth oxidation of the thiophene to the thiophene S-oxide to occur.

Next, 2,5-bis(tert-butyl)thiophene $S$-oxide $(\mathbf{1 c}),{ }^{24}$ prepared by oxidation of 2,5-bis(tertbutyl)thiophene with $m$-CPBA in the presence of $\mathrm{BF}_{3} \cdot \mathrm{Et}_{2} \mathrm{O},{ }^{4}$ was found to cycloadd to dienophiles with one electron-withdrawing substituent at $60{ }^{\circ} \mathrm{C}$. Cycloadducts 5 were obtained with $60-65 \%$ yield, again as single isomers (Scheme 3). The tert-butyl ester 5c could be hydrolyzed to carboxylic acid $\mathbf{5 d}$ without affecting the SO bridge. The reaction of 2,5-di-tertbutylthiophene $S$-oxide (1c) with $p$-naphthoquinone (2i) gave cycloadduct $\mathbf{5 b}$ in $72 \%$ yield (Scheme 3).

The reactivity of 2,5-di-tert-butylthiophene $S$-oxide (1c) in the cycloaddition reactions above was compared to that of 2,5-di-tert-butylthiophene $S, S$-dioxide (6), prepared by oxidation of 2,5-di-tert-butylthiophene with $m$-CPBA in the absence of $\mathrm{BF}_{3} \cdot \mathrm{Et}_{2} \mathrm{O}$. No reaction took place between 2,5-di-tert-butylthiophene $S, S$-dioxide (6) and dienophiles 2 at $60{ }^{\circ} \mathrm{C}$. With mono- and disubstituted acetylene dienophiles such as with benzyl propiolate, ethyl propiolate and diethyl acetylenedicarboxylate, $\mathbf{6}$ did not undergo a cycloaddition at even $100{ }^{\circ} \mathrm{C}$. $p$-Naphthoquinone (2i) and $N$-(p-chlorophenyl)maleimide (2h) cycloadded to $\mathbf{6}$, but at reaction temperatures of $195{ }^{\circ} \mathrm{C}$ and at $140{ }^{\circ} \mathrm{C}$, respectively. For these reactions diphenyl ether was used as solvent. At the reaction temperatures, the $\mathrm{SO}_{2}$ bridge of the primary cycloadducts extruded cleanly and in the case of the reaction with $p$-naphthoquinone (2i), 1,4-di-tert-butylanthraquinone (7b), and in the 


\section{ACCEPTED MANUSCRIPT}

case of the reaction with $N$-(p-chlorophenyl)maleimide $(\mathbf{2 h})$, a mixture of the corresponding ditert-butylphthalimide (7a) and di-tert-butyldihydrophthalimide (8a) was obtained (Scheme 4).

Oxidative extrusion of the sulfoxy bridge in cycloadducts similar to $\mathbf{3}$ and $\mathbf{5}$ have been reported to have been accomplished thermally ${ }^{25}$ or at room temperature when the reactions were run electrochemically, ${ }^{26}$ photochemically ${ }^{27}$ or using $\mathrm{KMnO}_{4}$ as oxidant under phase transfer conditions $^{25}$. Nevertheless, the electrochemical oxidative SO extrusion often leads to blockage of the electrodes after some time due to fouling. The oxidative extrusion with $\mathrm{KMnO}_{4}$ under phase transfer conditions can lead to variable results. Thus far, the photochemical SO extrusion has been studied for two cycloadducts, only. ${ }^{27}$

Thermal SO-extrusion reactions with 7-thiabicyclo[2.2.1]hept-5-ene $S$-oxides occur only at relatively high temperatures. Thus, 3a does not extrude $\mathrm{SO}$ even when kept at $130{ }^{\circ} \mathrm{C}(12 \mathrm{~h})$ in diphenylether. However, when 3a is heated in diphenylether at $160{ }^{\circ} \mathrm{C}$ for $14 \mathrm{~h}$, the SO-extruded and aromatized product 9a can be isolated with $75 \%$ yield (Scheme 5). At that temperature, the extrusion reaction is still slow, so that after $4 \mathrm{~h}$ an appreciable amount of starting material can be detected. Higher reaction temperatures $\left(180{ }^{\circ} \mathrm{C}\right)$ and shortened reaction times $(9 \mathrm{~h})$ give $9 \mathrm{a}$ with slightly lower yield.

1,4-Di-tert-butylthiabicyclo[2.2.1] hept-5-ene $S$-oxides 5 were found to extrude SO more readily (Scheme 6). When $N$-(p-chlorophenyl)-1,4-di-tert-butyl-7-thiabicyclo[2.2.1]hept-5-ene-2,3dicarboxamide $S$-oxide (5a) was heated in diphenyl ether at $140{ }^{\circ} \mathrm{C}$ for $1 \mathrm{~h}, N$-( $p$-chlorophenyl)3,6-di-tert-butylphthalimide (7a) was found with $74 \%$ yield, the remainder being starting material. Raising the temperature to $170{ }^{\circ} \mathrm{C}$ did not improve the yield of $\mathbf{7 a}$, however, and 


\section{ACCEPTED MANUSCRIPT}

produced a small amount (5\%) of $N$-(p-chlorophenyl)-3,6-di-tert-butyl-1,2-dihydrophthalimide (8a). Heating acetyl-1,4-di-tert-butyl-7-thiabicyclo[2.2.1]hept-5-ene $S$-oxide (5e) in diphenyl ether at $140{ }^{\circ} \mathrm{C}$ for 30 min gives $30 \%$ 2,5-di-tert-butylacetophenone (7c) with $60 \%$ of the starting material remaining (Scheme 6). After $1 \mathrm{~h}$ at $140{ }^{\circ} \mathrm{C}, 2,5$-di-tert-butylacetophenone (7c), which had been prepared previously by more tedious routes, was produced in $65 \%$ yield. ${ }^{28}$ Again, the tetrakis-( $p$-tolyl) substituted analog $\mathbf{3 e}$ required higher reaction temperatures and longer reaction times to give $\mathbf{9 b}$ with $70 \%$ yield (Scheme 5).

Some years ago, the authors studied the SO-photo-extrusion at room temperature of two 7thiabicyclo[2.2.1]hept-5-ene $S$-oxides, namely the products stemming formally from the cycloaddition of 2,5-dimethylthiophene $S$-oxide and of 2,3,4,5-tetramethylthiophene $S$-oxide with $\mathrm{N}$-phenylmaleimide. ${ }^{27}$ In both cases the SO bridge could be extruded photochemically to give methyl substituted $\mathrm{N}$-phenylphthalimides as the aromatized products. ${ }^{27}$ In the following, it was investigated whether this SO-photo-extrusion, which finds its counter-part in the photoextusion of the $\mathrm{CO}$ bridge in cycloadducts of tetraarylcyclopentadienones and alkenes, ${ }^{29}$ can be carried out with the cycloadducts prepared above. The cycloadducts were photo-irradiated in $\mathrm{CD}_{2} \mathrm{Cl}_{2}$ at $\lambda>222 \mathrm{~nm}$ without use of sensitizer. The reactions were screened for the aromatized compounds as the desired products. However no identification of potential minor side-products was carried out. The photoreactions were monitored by ${ }^{1} \mathrm{H}$ NMR spectroscopy. Photo-irradiation of tetraphenyl-7-thiabicyclo[2.2.1]hept-5-ene $S$-oxide 3i gave a mixture of dihydrophthalimide $\mathbf{8 b}$ and phthalimide 9c (Scheme 7). It is believed that the dihydrophthalimide is an intermediate in the photo-extrusion/oxidation reaction and that the extruded sulfur monoxide (SO) oxidizes $\mathbf{8 b}$

to 9 c. $\mathrm{SO}$ is a triplet in its ground state $\left(\mathrm{X}^{3} \Sigma^{-}\right)$and has two excited states $\left(\mathrm{a}^{1} \Delta\right)$ and $\left(\mathrm{b}^{1} \Sigma^{-}\right), 17.6$ 


\section{ACCEPTED MANUSCRIPT}

$\mathrm{kcal} / \mathrm{mol}$ and $30.0 \mathrm{kcal} / \mathrm{mol}$ above the ground state, respectively. ${ }^{30}$ The mercury lamp used in our experiment would have sufficient energy to elevate SO from $\left(\mathrm{X}^{3} \Sigma^{-}\right)$to $\left(\mathrm{a}^{1} \Delta\right)$. Nevertheless, SO $\left(a^{1} \Delta\right)$ deactivates quickly to $\mathrm{SO}\left(\mathrm{X}^{3} \Sigma^{-}\right) \cdot{ }^{31}$ Also $\mathrm{SO}\left(\mathrm{X}^{3} \Sigma^{-}\right)$has a short lifetime in solution but has been trapped in cycloaddition reactions, previously. ${ }^{32}$ In the present case, it is not clear whether SO $\left(a^{1} \Delta\right)$ or SO $\left(\mathrm{X}^{3} \Sigma^{-}\right)$is responsible for the aromatization step or whether another pathway operates. In the photoreaction of 3a, 3a was applied to a preparative TLC plate $(20 \times 20 \mathrm{~cm}$, silica gel $60 \mathrm{~F}_{254} 2 \mathrm{~mm}$, with concentration zone, from Merck KGaA). The plate was developed with ether/hexane 1:1, until a zone of starting material separated clearly from the line of application (from the concentration zone). Then, the zone was photo-irradiated directly with a UVP-Mineralight Lamp, model UVGL-15, at $\lambda=254 \mathrm{~nm}$. The plate was irradiated for $3 \times 20$ min. Once the two were well separated, the zone containing the starting material was photoirradiated again $(3 \times 20 \mathrm{~min}$.), where the product zone was protected from the irradiation by a cover of aluminum foil. The process was repeated one more time to give a total irradiation time of $3 \mathrm{~h}$. Overall, the photo-irradiation gave phthalimide 9a with 55\% yield. Scheme 7 shows further examples of SO-photo-extrusion with 7-thiabicyclo[2.2.1] hept-5-ene $S$-oxide substrates 3 leading to the aromatized products 9 .

\section{CONCLUSIONS}

Both 2,5-di-tert-butylthiophene $S$-oxide (1c) and 2,3,4,5-tetrakis(p-tolyl)thiophene $S$-oxide (1a) undergo cycloaddition reactions with mono- and bis-acceptor substituted alkenes furnishing highly substituted 7-thiabicyclo[2.2.1]hept-5-ene $S$-oxides 3 and $\mathbf{5}$ with acceptable yields. The reactivity difference between 2,5-di-tert-butylthiophene $S$-oxide (1c) and 2,5-di-tert- 


\section{ACCEPTED MANUSCRIPT}

butylthiophene $S, S$-dioxide (6) is pronounced, where 2,5-di-tert-butylthiophene $S$-oxide (1c) cycloadds to many of the electron-poor alkenes at $60{ }^{\circ} \mathrm{C}$, while 2,5 -di-tert-butylthiophene $S, S$ dioxide (6) needs $140{ }^{\circ} \mathrm{C}$ or more. Tetraarylthiophene $S$-oxides such as $\mathbf{1 a}$ and $\mathbf{1 b}$ are building blocks for oligoarylbenzenes and can be used alternatively to tetraarylcyclopentadienones (tetracyclones). Nevertheless, the SO-extrusion of the 7-thiabicyclo[2.2.1]hept-5-ene $S$-oxides 3 and 5 remains problematic, with needed temperatures of $140{ }^{\circ} \mathrm{C}$ or above. Nevertheless, the thermal extrusion yields some interesting, highly substituted aromatic compounds such as $\mathbf{7 c}$ or $\mathbf{9 e}{ }^{33}$ which were not easily accessible previously. Photochemical SO-extrusion has been carried out successfully with six cycloadducts (3a, 3d-f, and 3i), although reaction times remain long.

\section{EXPERIMENTAL}

\section{General remarks}

Melting points (mp., uncorrected) were determined on a Yanaco microscope hotstage. IR spectra $\left(v_{\max }, \mathrm{KBr} / \mathrm{cm}^{-1}\right)$ were measured with a JASCO IR-700 instrument. ${ }^{1} \mathrm{H}$ NMR spectra (at 270 MHz and 395.7 MHz) and ${ }^{13} \mathrm{C}$ NMR spectra (at $67.8 \mathrm{MHz}$ and $99.45 \mathrm{MHz}$ ) were recorded with a JEOL EX-270 and a JEOL Lambda 400 FT-NMR spectrometer, respectively. The chemical shifts are relative to TMS (solvent $\mathrm{CDCl}_{3}$ ). MS were measured with a JMS-01-SG-2spectrometer (EI, $70 \mathrm{eV}$ ). Column chromatography was carried out on Wakogel C-300. For the photo-irradiation in solution, a $1 \mathrm{~kW}$ Tokyo Rigaku high-pressure mercury lamp was used. The photochemistry on silica gel was carried out with a UVP-Mineralight Lamp, model UVGL-15, at $\lambda=254 \mathrm{~nm}$. PLC plates $\left(20 \times 20 \mathrm{~cm}\right.$; silica gel $60 \mathrm{~F}_{254} 2 \mathrm{~mm}$ from Merck KGaA) were used. 


\section{ACCEPTED MANUSCRIPT}

2,5-Di-tert-butylthiophene $S, S$-dioxide $(\mathbf{6})^{34}$ and 2,5-di-tert-butylthiophene $S$-oxide (1c) ${ }^{4}$ were prepared analogous to known procedures.

\section{Tetrakis(p-tolyl)thiophene S-oxide (1a).}

In an inert atmosphere, $n$-BuLi $(1.59 \mathrm{M}, 21.5 \mathrm{~mL}, 3.32 \mathrm{mmol})$ was added to a slurry of zirconocene dichloride $(5.0 \mathrm{~g}, 17.1 \mathrm{mmol})$ and bis $(p$-tolyl $)$ acetylene $(7.5 \mathrm{~g}, 34.2 \mathrm{mmol})$ in dry THF (150 mL) at $-78{ }^{\circ} \mathrm{C}$. Subsequently, the mixture was warmed to rt. and stirred for $3 \mathrm{~h}$. Next, the solution was cooled to $0{ }^{\circ} \mathrm{C}$ and thionyl chloride $(2.2 \mathrm{~g}, 18.8 \mathrm{mmol})$ in hexane $(10 \mathrm{~mL})$ was added within $30 \mathrm{~min}$. The resulting mixture was stirred at $\mathrm{rt}$ for $3 \mathrm{~h}$. After the reaction was complete, the mixture was poured into conc. aq. $\mathrm{NaHCO}_{3}(200 \mathrm{~mL})$. The product was extracted with $\mathrm{CH}_{2} \mathrm{Cl}_{2}(200 \mathrm{~mL})$ and the organic phase was washed with water $(200 \mathrm{~mL})$, dried over anhydrous $\mathrm{MgSO}_{4}$ and concentrated in vacuo. The residue was purified by flash column chromatography on silica gel (hexane/ether 1:1) to give 1a $(4.72 \mathrm{~g}, 10.2 \mathrm{mmol}, 60 \%)$ as a pale yellow solid; mp. $110{ }^{\circ} \mathrm{C}$. IR: 3025, 2918, 1502, 1324, 1182, 1116, 1087, 1062, 1018, 851, 832, 819, 731, 539, 519. ${ }^{1} \mathrm{H}$ NMR (270 MHz): $\delta 2.26\left(\mathrm{~s}, 6 \mathrm{H}, 2 \mathrm{CH}_{3}\right), 2.30\left(\mathrm{~s}, 6 \mathrm{H}, 2 \mathrm{CH}_{3}\right), 6.80(\mathrm{~d}, 4 \mathrm{H}$, $\left.{ }^{3} J=8.3 \mathrm{~Hz}\right), 6.94\left(\mathrm{~d}, 4 \mathrm{H},{ }^{3} J=7.9 \mathrm{~Hz}\right), 7.07\left(\mathrm{~d}, 4 \mathrm{H},{ }^{3} J=7.9 \mathrm{~Hz}\right), 7.25\left(\mathrm{~d}, 4 \mathrm{H},{ }^{3} J=8.1 \mathrm{~Hz}\right) .{ }^{13} \mathrm{C}$ NMR (67.8 MHz): $\delta 21.2,127.9,128.9,129.3,129.6,129.7,130.6,137.8,138.4,140.8,145.3$.

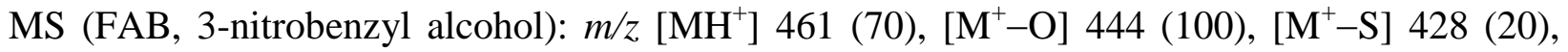
[M+-SO] 412 (30). Calcd. for $\mathrm{C}_{32} \mathrm{H}_{29} \mathrm{OS}$ : 461.1939. Found: 461.1940. HRMS Calcd. for $\mathrm{C}_{32} \mathrm{H}_{28}$ : 412.2191. Found: 412.2194. HRMS Calcd. for $\mathrm{C}_{32} \mathrm{H}_{28} \mathrm{O}$ : 428.2140. Found: 428.1247. Anal. Calcd. for $\mathrm{C}_{32} \mathrm{H}_{28} \mathrm{OS} \cdot 0.25 \mathrm{H}_{2} \mathrm{O}$ (465.13); C, 82.63; H, 6.12\%. Found C, 82.92; H, 6.31\%. 


\section{ACCEPTED MANUSCRIPT}

\section{N-Phenyl-3,4,5,6-tetrakis( $p$-tolyl)-7-thia-bicyclo[2.2.1]hept-5-ene-2,3-carboxamide}

\section{7-oxide (3a).}

A solution of tetrakis(p-tolyl)thiophene $S$-oxide $(1 \mathbf{1 a}, 87 \mathrm{mg}, 0.19 \mathrm{mmol})$ and $N$-phenylmaleimide (2a, $40 \mathrm{mg}, 0.23 \mathrm{mmol})$ in $\mathrm{CHCl}_{3}(1.5 \mathrm{~mL})$ was heated for $14 \mathrm{~h}$ at $50{ }^{\circ} \mathrm{C}$. The solution was concentrated in vacuo, and the residue was subjected to column chromatography on silica gel (hexane/ether 1:1) to give 3a (107 mg, 89\%) as a colorless solid, mp. $296{ }^{\circ} \mathrm{C}$. IR: 3026,2918 , $1716(\mathrm{C}=\mathrm{O}), 1503,1377,1188,1102,799,753,729 .{ }^{1} \mathrm{H}$ NMR (270 MHz): $\delta 2.14$ (s, 6H, $\left.2 \mathrm{CH}_{3}\right)$,

$2.30\left(\mathrm{~s}, 6 \mathrm{H}, 2 \mathrm{CH}_{3}\right), 4.95(\mathrm{~s}, 2 \mathrm{H}), 6.62\left(\mathrm{~d}, 4 \mathrm{H},{ }^{3} \mathrm{~J}=7.9 \mathrm{~Hz}\right), 6.71$ (d, $\left.4 \mathrm{H},{ }^{3} \mathrm{~J}=7.9 \mathrm{~Hz}\right), 7.00$ (vs, 8H), $7.24-7.36(\mathrm{~m}, 5 \mathrm{H}) .{ }^{13} \mathrm{C}$ NMR $(67.8 \mathrm{MHz}): \delta 21.150 .1,80.5,126.1,126.4,128.5,128.9$, 129.1, 129.2, 130.1, 130.5, 131.8, 134.2, 137.4, 138.0, 138.3, 174.3. MS (FAB, 3-nitrobenzyl

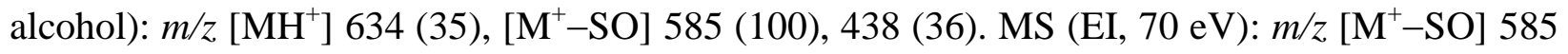
(100), 444 (44), 438 (41). HRMS Found: 634.2418. Calcd. for $\mathrm{C}_{42} \mathrm{H}\left(\mathrm{MH}^{+}, \mathrm{FAB}\right)$. Anal. Calcd. for $\mathrm{C}_{42} \mathrm{H}_{35} \mathrm{O}_{3} \mathrm{NS}$ (657.82); C, 79.59; H, 5.57; N, 2.21. Found C, 79.31; H, 5.66; N, 2.17\%.

\section{$N$-(p-Chlorophenyl)-1,4-di-tert-butyl-7-thiabicyclo[2.2.1]hept-5-ene-2,3-} dicarboxamide S-oxide (5a).

A mixture of 2,5-di-tert-butylthiophene $S$-oxide (1c, $80 \mathrm{mg}, 0.38 \mathrm{mmol})$ and $N$-(pchlorophenyl)maleimide (2h, $79 \mathrm{mg}, 0.38 \mathrm{mmol})$ in $\mathrm{CHCl}_{3}(1.5 \mathrm{~mL})$ was heated for $12 \mathrm{~h}$ at 60 ${ }^{\circ} \mathrm{C}$. The solution was concentrated in vacuo, and the residue was subjected to column chromatography on silica gel (chloroform/hexane/ether 1:1:1) to give 5a (142 $\mathrm{mg}, 89 \%)$ as a colorless solid, mp. $213^{\circ} \mathrm{C}$. IR: $1710(\mathrm{C}=\mathrm{O}) .{ }^{1} \mathrm{H}$ NMR $(270 \mathrm{MHz}): \delta 1.32\left(\mathrm{~s}, 18 \mathrm{H}, 6 \mathrm{CH}_{3}\right), 7.11$ $\left(\mathrm{d}, 2 \mathrm{H},{ }^{3} \mathrm{~J}=8.0 \mathrm{~Hz}\right), 7.34\left(\mathrm{~d}, 2 \mathrm{H},{ }^{3} \mathrm{~J}=8.0 \mathrm{~Hz}\right) .{ }^{13} \mathrm{C} \mathrm{NMR}(67.8 \mathrm{MHz}): \delta 28.7\left(6 \mathrm{C}, 6 \mathrm{CH}_{3}\right), 33.5$ 


\section{ACCEPTED MANUSCRIPT}

(2C, $\left.\mathrm{C}_{\text {quat }}, \underline{\mathrm{C}}\left(\mathrm{CH}_{3}\right)_{3}\right), 48.3(2 \mathrm{C}, \mathrm{CH}), 80.7\left(2 \mathrm{C}, \mathrm{C}_{\text {quat }}\right), 127.9(2 \mathrm{C}, \mathrm{CH}), 129.3(2 \mathrm{C}, \mathrm{CH}), 129.5$ $\left(\mathrm{C}_{\text {quat }}\right), 130.3(2 \mathrm{C}, \mathrm{CH}), 134.7\left(\mathrm{C}_{\text {quat }}\right), 173.9$ (2C, $\left.\mathrm{C}_{\text {quat }}, \mathrm{CO}\right) . \mathrm{MS}$ (FAB, 3-nitrobenzyl alcohol): $m / z\left[\left[{ }^{37} \mathrm{Cl}\right] \mathrm{MH}^{+}\right] 422$ (7), [[ $\left.\left.{ }^{35} \mathrm{Cl}\right] \mathrm{MH}^{+}\right] 420$ (17), [[ $\left.\left.{ }^{35} \mathrm{Cl}\right] \mathrm{M}^{+}-\mathrm{SO}\right] 371$ (13), 154 (100), 136 (82). HRMS Found: 420.1396. Calcd. for $\mathrm{C}_{22} \mathrm{H}_{27} \mathrm{O}_{3} \mathrm{~N}^{35} \mathrm{ClS}: 420.1400\left(\left[{ }^{35} \mathrm{Cl}^{3} \mathrm{MH}^{+}, \mathrm{FAB}\right)\right.$.

\section{$N$-(p-Chlorophenyl)-3,6-di-tert-butylphthalimide (7a).}

Method A: A solution of $\mathbf{6}(196 \mathrm{mg}, 0.86 \mathrm{mmol})$ and $N$-chlorophenylmaleimide $(\mathbf{2 h}, 284 \mathrm{mg}$, $1.37 \mathrm{mmol})$ in deaerated diphenyl ether $(1 \mathrm{~g}, 930 \mu \mathrm{L})$ was heated at $140{ }^{\circ} \mathrm{C}$ for $17 \mathrm{~h}$. Thereafter, the cooled solution was subjected to column chromatography on silica gel (hexane to elute the solvent, then hexane/CHCl $3 /$ ether 2:1:1) to give 7a $(110 \mathrm{mg}, 35 \%)$ as a colorless solid, mp. 214 ${ }^{\circ} \mathrm{C} .{ }^{1} \mathrm{H}$ NMR (270 MHz): $\delta 1.54\left(\mathrm{~s}, 18 \mathrm{H}, 2 \mathrm{Bu}^{t}\right), 7.40\left(\mathrm{~d}, 2 \mathrm{H},{ }^{3} J=8.9 \mathrm{~Hz}\right), 7.48\left(\mathrm{~d}, 2 \mathrm{H},{ }^{3} J=8.9\right.$ $\mathrm{Hz}), 7.71(\mathrm{~s}, 2 \mathrm{H}) ;{ }^{13} \mathrm{C}$ NMR (67.8 MHz): $\delta 30.5\left(6 \mathrm{C}, 6 \mathrm{CH}_{3}\right), 36.0\left(2 \mathrm{C}, \mathrm{C}_{\text {quat }}, \underline{\mathrm{C}}\left(\mathrm{CH}_{3}\right)_{3}\right), 129.0$ (2C, $\mathrm{CH}), 129.7(2 \mathrm{C}, \mathrm{CH}), 132.1\left(\mathrm{C}_{\text {quat }}\right), 133.5(2 \mathrm{C}, \mathrm{CH}), 142.5\left(\mathrm{C}_{\text {quat }}\right), 150.1\left(2 \mathrm{C}, \mathrm{C}_{\text {quat }}\right), 157.6$ (2C, $\left.\mathrm{C}_{\text {quat }}\right), 188.8\left(2 \mathrm{C}, \mathrm{C}_{\text {quat }}, \mathrm{CO}\right) . \mathrm{MS}(\mathrm{EI}, 70 \mathrm{eV}): \mathrm{m} / \mathrm{z}\left[\left[^{37} \mathrm{Cl}\right] \mathrm{M}^{+}\right] 371(37),\left[\left[{ }^{35} \mathrm{Cl}\right] \mathrm{M}^{+}\right] 369$ (100), $\left[{ }^{35} \mathrm{Cl}^{3} \mathrm{M}^{+}-\mathrm{CH}_{3}\right] 354$ (84). HMRS Found: 369.1496. Calcd. for $\mathrm{C}_{22} \mathrm{H}_{24} \mathrm{O}_{2} \mathrm{~N}^{35} \mathrm{Cl}: 369.1496$ and $N$-(p-chlorophenyl)-3,6-di-tert-butyl-1,2-dihydrophthalimide (8a) (16 mg, 5\%) as a colorless solid, mp. $200{ }^{\circ} \mathrm{C} .{ }^{1} \mathrm{H}$ NMR (270 MHz): $\delta 1.19$ (s, 18H, $\left.2 \mathrm{Bu}^{t}\right), 3.91$ (s, 2H), 6.06 (s, 2H), 7.28 $\left(\mathrm{d}, 2 \mathrm{H},{ }^{3} \mathrm{~J}=8.6 \mathrm{~Hz}\right), 7.41\left(\mathrm{~d}, 2 \mathrm{H},{ }^{3} J=8.6 \mathrm{~Hz}\right) ;{ }^{13} \mathrm{C} \mathrm{NMR}(67.8 \mathrm{MHz}): \delta 29.9\left(6 \mathrm{C}, 6 \mathrm{CH}_{3}\right), 36.0$ (2C, $\left.\mathrm{C}_{\text {quat }}, \underline{\mathrm{C}}\left(\mathrm{CH}_{3}\right)_{3}\right), 47.4(2 \mathrm{C}, \mathrm{CH}), 120.8(2 \mathrm{C}, \mathrm{CH}), 126.7(2 \mathrm{C}, \mathrm{CH}), 129.6(2 \mathrm{C}, \mathrm{CH}), 131.1$ $\left(\mathrm{C}_{\text {quat }}\right), 134.4\left(\mathrm{C}_{\text {quat }}\right), 139.9\left(\mathrm{C}_{\text {quat }}\right), 178.0\left(2 \mathrm{C}, \mathrm{C}_{\text {quat }}, \mathrm{CO}\right)$; $\left.\mathrm{MS}(\mathrm{EI}, 70 \mathrm{eV}): \mathrm{m} / z\left[{ }^{37} \mathrm{Cl}\right] \mathrm{M}^{+}\right] 373$ (11), $\left[{ }^{35} \mathrm{Cl}^{-} \mathrm{M}^{+}\right] 371$ (31), [[ $\left.{ }^{35} \mathrm{Cl} \mathrm{M}^{+}-\mathrm{CH}_{3}\right] 356$ (19), 175 (100). HRMS Found: 371.1654. Calcd. for $\mathrm{C}_{22} \mathrm{H}_{26} \mathrm{O}_{2} \mathrm{~N}^{35} \mathrm{Cl}: 371.1652$. 


\section{ACCEPTED MANUSCRIPT}

Method B: A solution of $\mathbf{5 a}(50 \mathrm{mg}, 0.12 \mathrm{mmol})$ in diphenyl ether $(2 \mathrm{~mL})$ was heated at $170{ }^{\circ} \mathrm{C}$ for $1 \mathrm{~h}$. Thereafter, the cooled solution was subjected to column chromatography on silica gel (hexane to elute the solvent, then hexane/ $\mathrm{CHCl}_{3} /$ ether 2:1:1) to give $7 \mathbf{a}(30.6 \mathrm{mg}, 69 \%)$ and $\mathrm{N}$ (p-chlorophenyl)-3,6-bis(tert-butyl)-1,2-dihydrophthalimide (8a) (2.4 mg, 5\%).

\section{N-Phenyl-3,4,5,6-tetrakis(p-tolyl)phthalimide (9a).}

Method A: $N$-Phenyl-1,4,5,6-tetrakis( $p$-tolyl)-7-thiabicyclo[2.2.1]hept-5-ene-2,3-dicarboxamide $S$-oxide (3a, $33 \mathrm{mg}, 0.05 \mathrm{mmol})$ in diphenyl ether $(450 \mathrm{mg}, 420 \mu \mathrm{L})$ was heated to $180{ }^{\circ} \mathrm{C}$ for 9 h. Thereafter, the cooled solution was subjected to column chromatography on silica gel (initially hexane, to elute the solvent diphenyl ether, then hexane/ether 1:1) to give $9 \mathbf{a}(20 \mathrm{mg}, 65 \%)$ as a colorless solid; IR: 2920, $1721(\mathrm{C}=\mathrm{O}), 1601,1368,1114,805,763,722 .{ }^{1} \mathrm{H}$ NMR $(270 \mathrm{MHz}): \delta$ $2.12\left(\mathrm{~s}, 6 \mathrm{H}, 2 \mathrm{CH}_{3}\right), 2.27\left(\mathrm{~s}, 6 \mathrm{H}, 2 \mathrm{CH}_{3}\right), 6.62\left(\mathrm{~d}, 4 \mathrm{H},{ }^{3} \mathrm{~J}=7.9 \mathrm{~Hz}\right), 6.71\left(\mathrm{~d}, 4 \mathrm{H},{ }^{3} \mathrm{~J}=7.9 \mathrm{~Hz}\right)$, 7.00 (vs, 8H), 7.24 - 7.36 (m, 5H). MS (FAB, 3-nitrobenzyl alcohol): m/z 584 (MH', 49). HRMS Found: 584.2591. Calcd. for $\mathrm{C}_{42} \mathrm{H}_{34} \mathrm{O}_{2} \mathrm{~N}$ : $584.2590\left(\mathrm{MH}^{+}\right)$.

Method B: 3a (19.7 mg, $0.031 \mathrm{mmol})$ was dissolved in $\mathrm{CHCl}_{3}(2 \mathrm{~mL})$ and applied to a preparative TLC plate $\left(20 \times 20 \mathrm{~cm}\right.$, silica gel $60 \mathrm{~F}_{254} 2 \mathrm{~mm}$, with concentration zone, from Merck $\mathrm{KGaA}$ ). The plate was run with ether/hexane 1:1, until a zone of starting material separated clearly from the line of application (from the concentration zone). Then, the zone was photoirradiated directly with a UVP-Mineralight Lamp, model UVGL-15, at $\lambda=254 \mathrm{~nm}$. The plate was irradiated for $3 \times 20 \mathrm{~min}$. Then, the plate was developed once more with hexane/ether 1:1, to separate the product from the starting material. Once the two were well separated, the zone containing the starting material was photo-irradiated again $(3 \times 20 \mathrm{~min}$.), where the product zone 


\section{ACCEPTED MANUSCRIPT}

was protected from the irradiation by a cover of aluminum foil. The process was repeated once more to give a total irradiation time of $3 \mathrm{~h}$. Thereafter, the remaining starting material was separated from the zones of product formed in the three photo-irradiation processes. The product containing silica gel was taken off the plate and transferred to a short column fitted with a cotton pad. The substance was eluted off the column with ether. The column was washed once with $\mathrm{CHCl}_{3}$. The eluted fractions were concentrated in vacuo to give $9 \mathbf{a}(10 \mathrm{mg}, 55 \%)$.

\section{2,3,4,5-Tetrakis(p-tolyl)acetophenone (9b)}

Method A: A solution of $3 \mathbf{e}\left(50 \mathrm{mg}, 9.4 \cdot 10^{-5} \mathrm{~mol}\right)$ in diphenyl ether $(500 \mathrm{mg}, 460 \mu \mathrm{L})$ was heated to $170{ }^{\circ} \mathrm{C}$ for $9 \mathrm{~h}$. The cooled solution was subjected directly to column chromatography on silica gel (initially hexane to elute the solvent, thereafter hexane/ether 1:1) to give $\mathbf{9 b}(31.5 \mathrm{mg}, 70 \%)$ as a colorless solid. IR: 3022, 2920, 2856, 1688, 1517, 111, 1029, 813. ${ }^{1} \mathrm{H}$ NMR (270 MHz): $\delta 1.90\left(\mathrm{~s}, 3 \mathrm{H}, \mathrm{COC}_{3}\right), 2.12\left(\mathrm{~s}, 3 \mathrm{H}, \mathrm{CH}_{3}\right), 2.14\left(\mathrm{~s}, 3 \mathrm{H}, \mathrm{CH}_{3}\right), 2.27\left(\mathrm{~s}, 6 \mathrm{H}, 2 \mathrm{CH}_{3}\right), 6.59-6.74(\mathrm{~m}$, $8 \mathrm{H}), 6.89\left(\mathrm{~d}, 2 \mathrm{H},{ }^{3} \mathrm{~J}=8.1 \mathrm{~Hz}\right), 6.93\left(\mathrm{~d}, 2 \mathrm{H},{ }^{3} \mathrm{~J}=8.1 \mathrm{~Hz}\right), 6.97(\mathrm{vs}, 4 \mathrm{H}) ; \mathrm{MS}(\mathrm{EI}, 70 \mathrm{eV}): \mathrm{m} / z\left[\mathrm{M}^{+}\right]$ 480 (100), $\left[\mathrm{M}^{+}-\mathrm{CH}_{3}\right] 465$ (54), $\left[\mathrm{M}^{+}-\mathrm{C}_{2} \mathrm{H}_{2} \mathrm{O}\right] 438$ (41), 149 (29). HRMS Found: 480.2456. Calcd. for $\mathrm{C}_{36} \mathrm{H}_{22} \mathrm{O}: 480.2453$.

Method B: A solution of $3 \mathbf{e}\left(16.6 \mathrm{mg}, 3.1 \times 10^{-5} \mathrm{~mol}\right)$ in $\mathrm{CD}_{2} \mathrm{Cl}_{2}(0.5 \mathrm{~mL})$ was photo-irradiated with a $1 \mathrm{~kW}$ Tokyo Rigaku high-pressure mercury lamp, with the reaction system cooled at $\mathrm{rt}$. The mixture was analyzed by ${ }^{1} \mathrm{H}$ NMR spectroscopy after $30 \mathrm{~min} ., 2.5 \mathrm{~h}$ and $4 \mathrm{~h}$, after which the photo-irradiation was stopped. The mixture was subjected to column chromatography on silica gel (hexane/ether 1:1) to give $\mathbf{9 b}(9.8 \mathrm{mg}, 65 \%)$. 


\section{ACCEPTED MANUSCRIPT}

\section{Acknowledgements}

This project was supported in part by ESPRC (in UK) and J. Iniesta thanks the ESPRC for funding of a stay at Kyushu University, Fukuoka, Japan. The authors thank Ms. Y. Tanaka for carrying out the mass and high resolution mass spectroscopic measurements of the compounds. The elemental analyses were carried out at the Central Analysis Center, Hakozaki Campus, Kyushu University. 


\section{ACCEPTED MANUSCRIPT}

\section{REFERENCES}

[1] (a) Yoshida, K.; Horiuchi, S.; Iwadate, N.; Kawagoe, F.; Imamoto, T. Synlett 2007, 1561-1562. (b) Yoshida, K.; Hayashi, A; Yanagisawa, Org. Lett. 2011, 9, 4627-4630.

[2] (a) Hilt, G.; Danz, M. Synthesis 2008, 2257-2263. (b) Hilt, G.; Smolko, K. I. Angew. Chem. Int. Ed. 2003, 42, 2795-2797.

[3] (a) Horie, H.; Kurahashi, T.; Matsubara, S. J. Chem. Soc., Chem. Commun. 2012, $3866-3868$.

[4] Thiemann, T.; Fujii, H.; Ohira, D.; Arima, K.; Li, Y. Q.; Mataka, S. New J. Chem. 2003, 27, 1377-1384.

[5] (a) Pérez, D.; Peňa, D.; Guitián, E. Eur. J. Org. Chem. 2013, 5981-6013; (b) Hayes, M. E.; Shinokubo, H.; Danheiser, R. L. Org. Lett. 2005, 7, 3917-3920.

[6] (a) Woodard, B. T.; Posner, G. H. Advances in Cycloaddition 1999, 5, 47-83. (b) Delaney, P. M.; Moore, J. E.; Harrity, J. P. A. J. Chem. Soc., Chem. Commun. 2006, $3323-3325$.

[7] (a) Buszek, K. R. Tetraphenylcyclopentadienone, e-EROS Encyclopedia of Reagents for Organic Synthesis, 2001; (b) Hapke, M.; Gutnov, A.; Weding, N.; Spannenberg, A.; Fischer, C.; Benkhäuser-Schunk C.; Heller, B. Eur. J. Org. Chem. 2010, 509-514. (c) Khazaei, A.; Zolfigol, M. A.; Manesh, A. A. J. Chin. Chem. Soc. 2013, 52, 515-518.

[8] Padwa, A.; Dimitroff, M.; Waterson, A. G.; Wu, T. J. Org. Chem. 1997, 62, 4088-4096. 


\section{ACCEPTED MANUSCRIPT}

[9] (a) Kumamoto, K.; Fukuda, I.; Kotsuki, H. Angew. Chem. Int. Ed. Engl. 2004, 43, 2015-2017. (b) Helder, R.; Wynberg, H. Tetrahedron Lett. 1972, 605-608. (c). Kuhn, H.-J.; Gollnick, K. Chem. Ber. 1973, 106, 674-696. (d) Corral, C.; Lissavetzky, J.; Manzanares, I. Synthesis 1997, 29-31.

[10] (a) Melles, J. L. Recl. Trav. Chim. Pays-Bas 1952, 71, 869-878. (b) Nakayama, J.; Hirashima, A. J. Am. Chem. Soc. 1990, 112, 7648-7653. (c) Moiseev, A. M.; Tyurin, D. D.; Balenkova, E. S.; Nenajdenko, V. G. Tetrahedron 2006, 62, 4139-4145. (d) Van Tilborg, W. J. M.; Smael, P.; Viser, T. P.; Louwenhoven, C. G.; Reinhoudt, D. N. Rec. Trav. Chim. Pays-Bas, 1975, 94, 85-88.

[11] (a) Li, Y. Q.; Matsuda, M.; Thiemann, T.; Sawada, T.; Mataka, S.; Tashiro, M. Synlett 1996, 461-464. (b) Furukawa, N.; Zhang, S.-Z.; Sato, S.; Higaki, M. Heterocycles 1997, 44, 61-66. (c) Li, Y. Q.; Thiemann, T.; Sawada, T.; Mataka, S.; Tashiro, M. J. Org. Chem. 1997, 62, 7926-7936. (d) Nakayama, J.; Yu, T.; Sugihara, Y.; Ishii, A. Chem. Lett. 1997, 26, 499-500. (e) Furukawa, N.; Zhang, S.-Z.; Horn, E.; Takahashi, O.; Sato, S.; Heterocycles 1998, 47, 793-809. (f) Takayama, J.; Sugihara, Y.; Takayanagi, T.; Nakayama, J. Tetrahedron Lett. 2005, 46, 4165-4169. (g) Pouzet, P.; Erdelmeier, I.; Ginderow, D.; Mornon, J.-P.; Dansette, P. M.; Mansuy D. J. Chem. Soc., Chem. Commun. 1995, 473-474.

[12] (a) For reviews, see: Lu, Y.; Dong, Z.; Wang, P.; Zhou, H.-B. Top. Heterocycl. Chem. 2015, 39, 227-294. (b) Thiemann, T.; Iniesta, J. Research Trends in Heterocyclic 


\section{ACCEPTED MANUSCRIPT}

Chemistry 2011, 15, 71-88. (c) Thiemann, T.; Gopal Dongol, K. J. Chem. Res. (S) 2002, 26, 303 - 308; (M) 2002, 701-708. (d) Thiemann, T.; Walton, D. J.; Brett, A. O.; Iniesta, J.; Marken, F.; Li, Y. Q. ARKIVOC 2009, Vol. ix, 96-113. (e) Nakayama, J. Bull. Chem. Soc. Jpn. 2000, 73, 1-17.

[13] (a) Arima, K.; Ohira, D.; Watanabe, M.; Miura, A.; Mataka, S.; Thiemann, T.; Iniesta, J.; Walton, D. Photochem. Photobiol. Sci. 2005, 4, 808-816; (b) Nakayama, J.; Hiraiwa, S. Fujihara, T. Sulfur Chem. 2008, 29, 243-250; (c) Heying, M. J.; Nag, M.; Jenks, W. S. J. Phys. Chem. Org. 2008, 21, 915-924.

[14] Jiang, B.; Tilley, T. D. J. Am. Chem. Soc. 1999, 121, 9744-9745.

[15] Suzuki, S.; Segawa, Y.; Itami, K.; Yamaguchi, J. Nature Chemistry 2015, 7, 227-233.

[16] Landini, D.; Rolla, F. J. Org. Chem. 1982, 47, 154-157.

[17] (a) Li, Y. Q.; Thiemann, T.; Mimura, K.; Sawada, T.; Mataka, S.; Tashiro, M. Eur. J. Org. Chem. 1998, 1841-1850. (b) Thiemann, T.; Li, Y. Q.; Thiemann, C.; Sawada, T.; Ohira, D.; Tashiro, M.; Mataka, S. Heterocycles 2000, 52, 1215-1230.

[18] (a) Cieplak, A. S. J. Am. Chem. Soc. 1981, 103, 4540-4552. (b) Cieplak, A. S.; Tait, B. D.; Johnson, C. R. J. Am. Chem. Soc. 1989, 111, 8447-8462. (c) Cieplak, A. S. Chem. Rev. 1999, 99, 1265-1336.

[19] Thiemann, T.; Iniesta, J.; Walton, D. J. Chem. Res. 2008, 32, 173-180.

[20] Iniesta, J.; Matsumoto, T.; Thiemann, T. J. Chem. Res. 2008, 32, 119-114. 


\section{ACCEPTED MANUSCRIPT}

[21] (a) Fogel, Y.; Zhi, L.; Rouhanipour, A.; Andrienko, D.; Räder, H. J.; Müllen, K. Macromolecules, 2009, 42, 6878-6884. (b) Englert, J. M.; Malig, J.; Zamolo, V. A.; Hirsch, A.; Jux, N. J. Chem. Soc., Chem. Commun. 2013, 49, 4827-4829.

[22] (a) Luo, Q.; Wang, C.; Zhang, W.-X.; Xi, Z. J. Chem. Soc., Chem. Commun. 2008, 15931595; (b) Xi, Z.; Song, Q. J. Org. Chem. 2000, 65, 9157-9159.

[23] Harmata, M.; Gomes, M. G. Eur. J. Org. Chem. 2006, 2273-2277.

[24] Mock, W. L., J. Am. Chem. Soc. 1970, 92, 7610-7612.

[25] Li, Y. Q.; Thiemann, T; Sawada, T.; Tashiro, M. J. Chem. Soc., Perkin Trans. 1, 1994, $2323-2329$.

[26] Thiemann, T.; Sa e Melo, M. L.; Campos Neves, A. S.; Li, Y. Q.; Mataka, S.; Tashiro, M.; Geißler, U.; Walton, D. J. Chem. Res. 1998, 22, 346-347.

[27] Thiemann, C.; Thiemann, T.; Li, Y. Q.; Sawada, T.; Nagano, Y.; Tashiro, M. Bull. Chem. Soc. Jpn. 1994, 67, 1886-1893.

[28] (a) Nightingale, D. V.; Hucker, H. B. J. Org. Chem. 1953, 48, 1529-1537. (b) Kagechika, H.; Kawachi, E.; Hashimoto, Y.; Shudo, K. J. Med. Chem. 1988, 31, 2182-2192. (c) Sudha, S.; Palanichamy, M.; Balasubramanian, V. V.; Arabindoo, B.; Murugesan, V. J. Mol. Catal. A 2006, 255, 220-229. (d) Dhami, K. S.; Stothers, J. B.; Tetrahedron Lett. 1964, 631-639. (e) Dhami, K. S.; Stothers, J. B. Can. J. Chem. 1965, 479-497.

[29] Fuchs, B. Isr. J. Chem. 1968, 6, 517-520. 


\section{ACCEPTED MANUSCRIPT}

[30] Swope, W. C.; Lee, Y.-P.; Schaefer III, H. F. J. Chem. Phys. 1979, 71, 3761-3769.

[31] Beckenridge, W. H.; Miller, T. A, J. Chem. Phys. 1972, 56, 465-474.

[32] Chao, P.; Lemal, D. M. J. Am. Chem. Soc. 1973, 95, 920-922.

[33] Tong, L.; Lau, H.; Ho, D. M.; Pascal, Jr., R. A. J. Am. Chem. Soc. 1998, 120, 6000-6006.

[34] Van Tilborg, W. J. M. Synth. Commun. 1976, 6, 583-589. 


\section{ACCEPTED MANUSCRIPT}

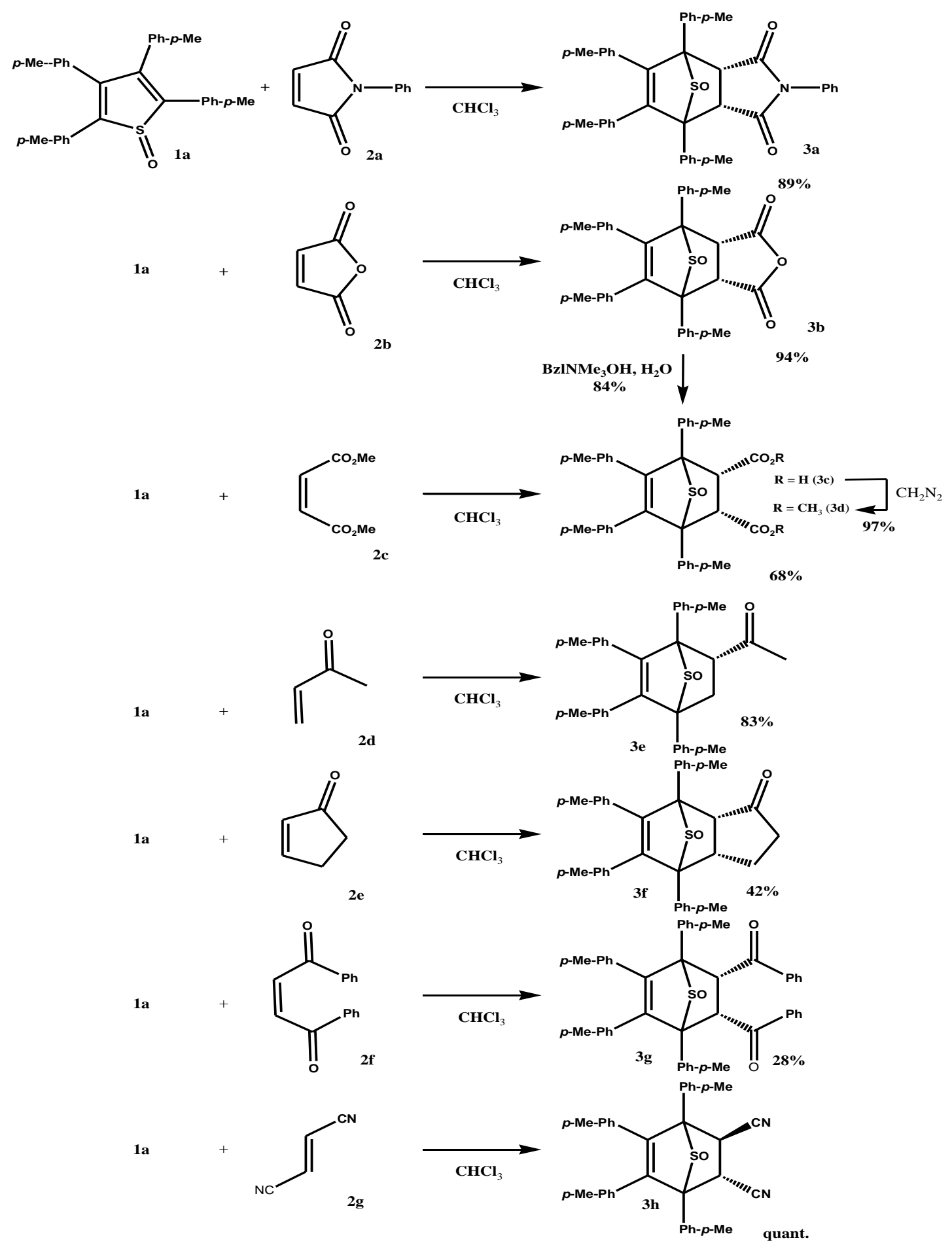

Scheme 1 


\section{ACCEPTED MANUSCRIPT}

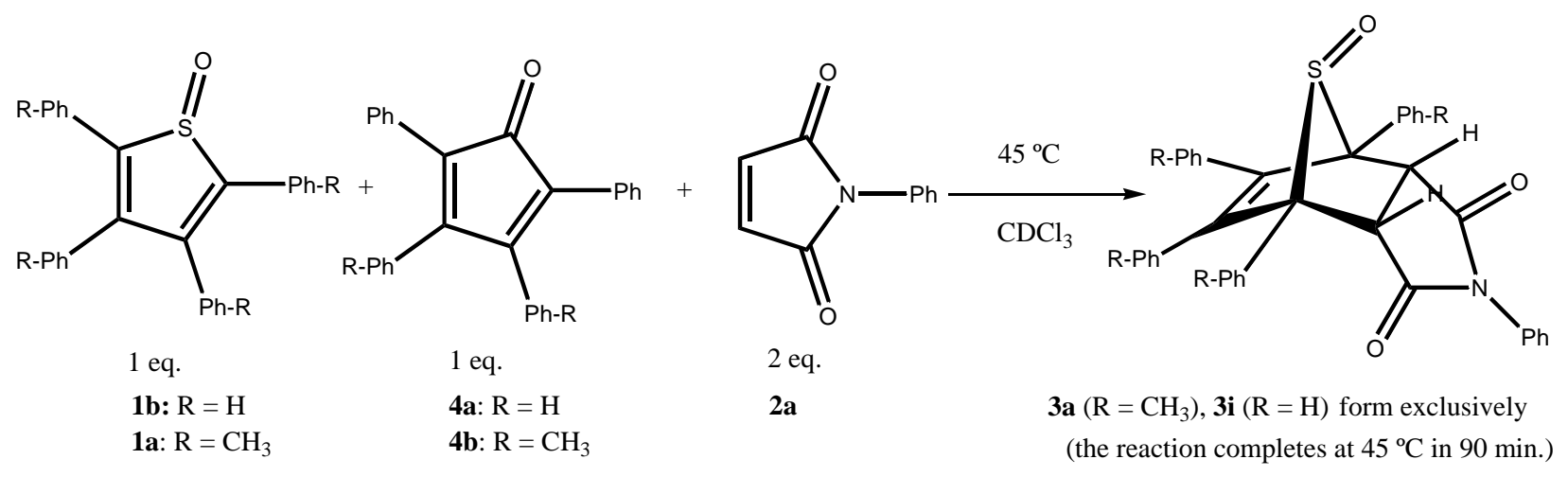

Scheme 2 


\section{ACCEPTED MANUSCRIPT}<smiles>O=S1C(Br)=CC=C1Br</smiles>

1c<smiles>O=C1C=CC(=O)c2ccccc21</smiles>

$1 \mathbf{c}$<smiles>C=CC(=O)OCC</smiles>

$2 \mathbf{j}$<smiles>C=CC(C)=O</smiles>

2d

1c +<smiles>O=C1C=CCC1</smiles>

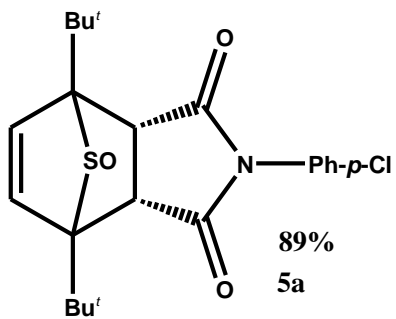<smiles>O=C1c2ccccc2C(=O)[C@@H]2[C@@H]1C1(Cc3ccccc3)C=C[C@]2(Cc2ccccc2)S1</smiles>
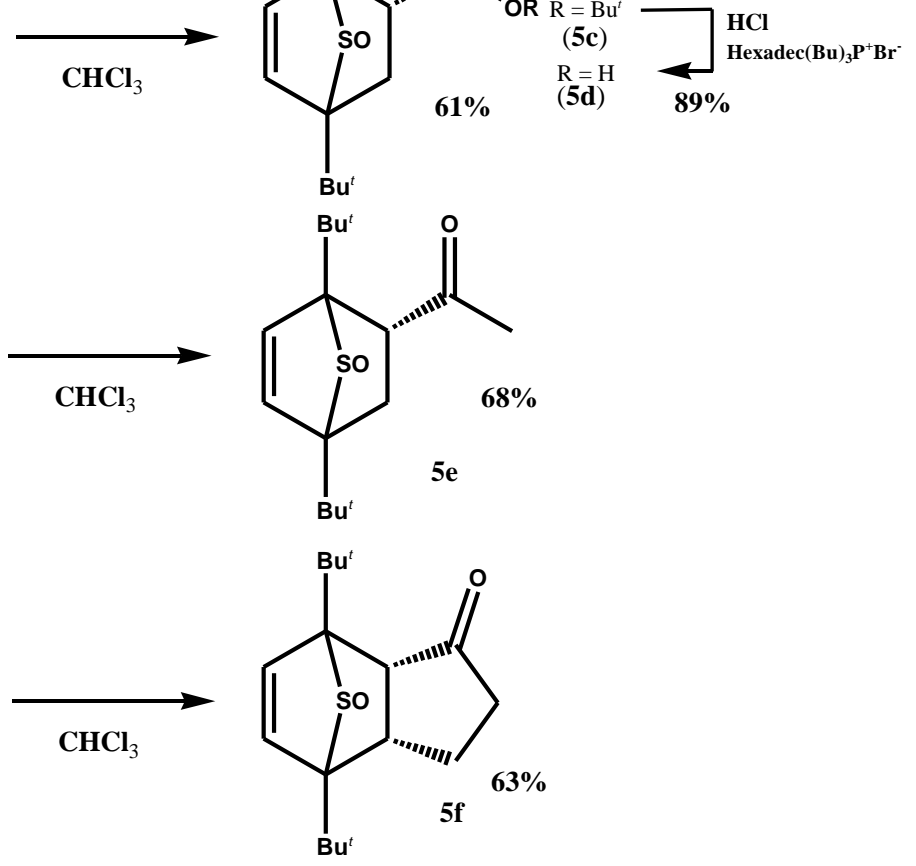

Scheme 3 


\section{ACCEPTED MANUSCRIPT}

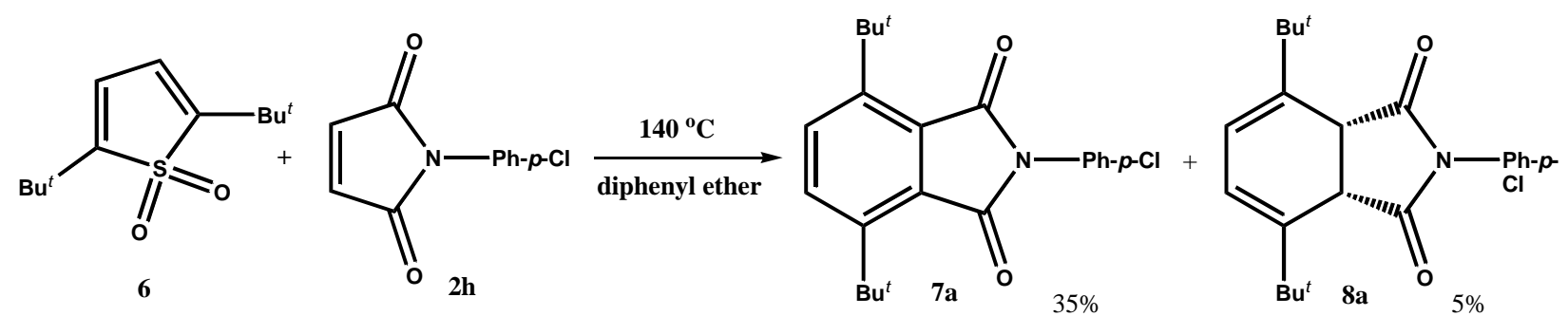<smiles>CC(C)Cc1ccc(Br)c2c1C(=O)c1ccccc1C2=O</smiles>

Scheme 4 


\section{ACCEPTED MANUSCRIPT}

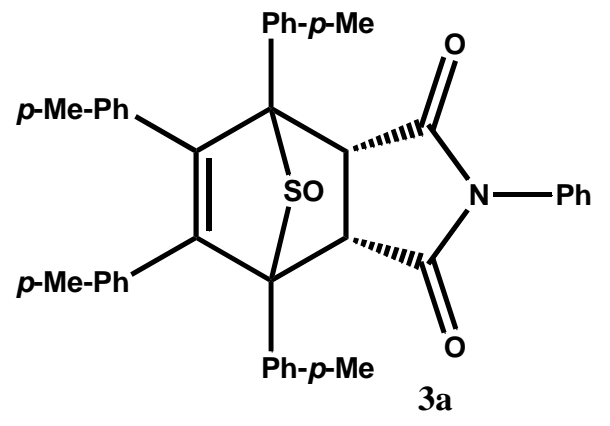<smiles>CC(=O)[C@@H]1CC2(c3ccccc3)[SeH]C1(P(C)c1ccccc1)C(c1ccccc1)=C2c1ccccc1</smiles>

$180{ }^{\circ} \mathrm{C}, 9 \mathrm{~h}$

diphenyl ether

$\underset{\text { diphenyl ether }}{\stackrel{170}{ }{ }^{\circ} \mathrm{C}, 9 \mathrm{~h}}$

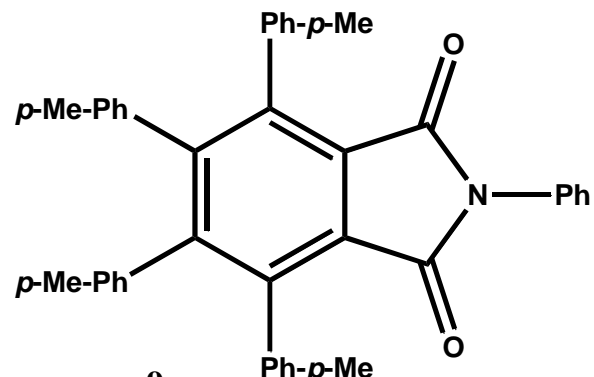

9a

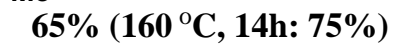<smiles>COc1cc(-c2ccccc2)c(-c2ccccc2)c(-c2ccccc2)c1-c1ccccc1</smiles>

Scheme 5 


\section{ACCEPTED MANUSCRIPT}
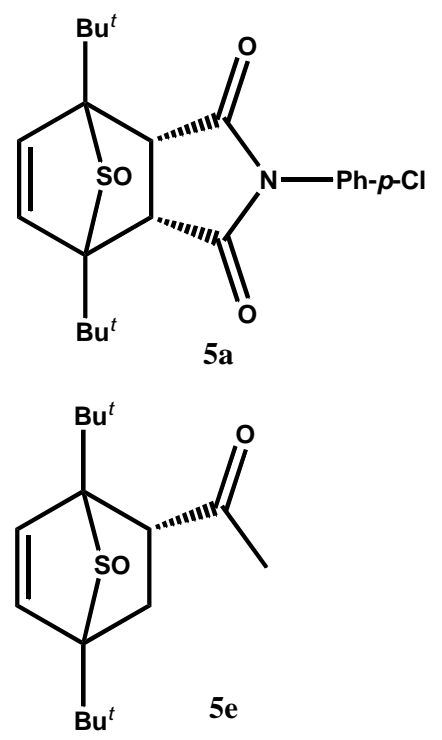

$\underset{\text { diphenyl ether }}{\stackrel{170}{ }{ }^{\circ} \mathrm{C}, 1 \mathrm{~h}}$

$140{ }^{\circ} \mathrm{C}, 1 \mathrm{~h}$

diphenyl ether

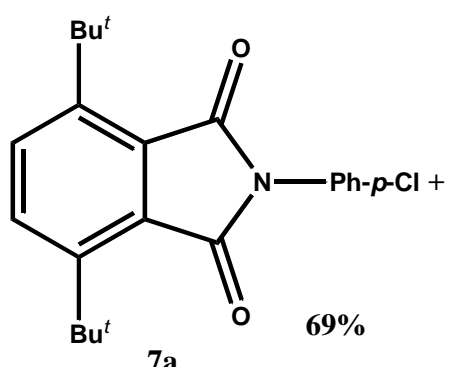

$7 \mathbf{a}$<smiles>CC(=O)c1cc(Br)ccc1Br</smiles>

$65 \%$

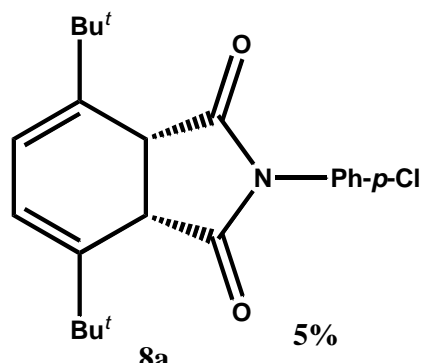

$8 \mathbf{a}$

Scheme 6 


\section{ACCEPTED MANUSCRIPT}
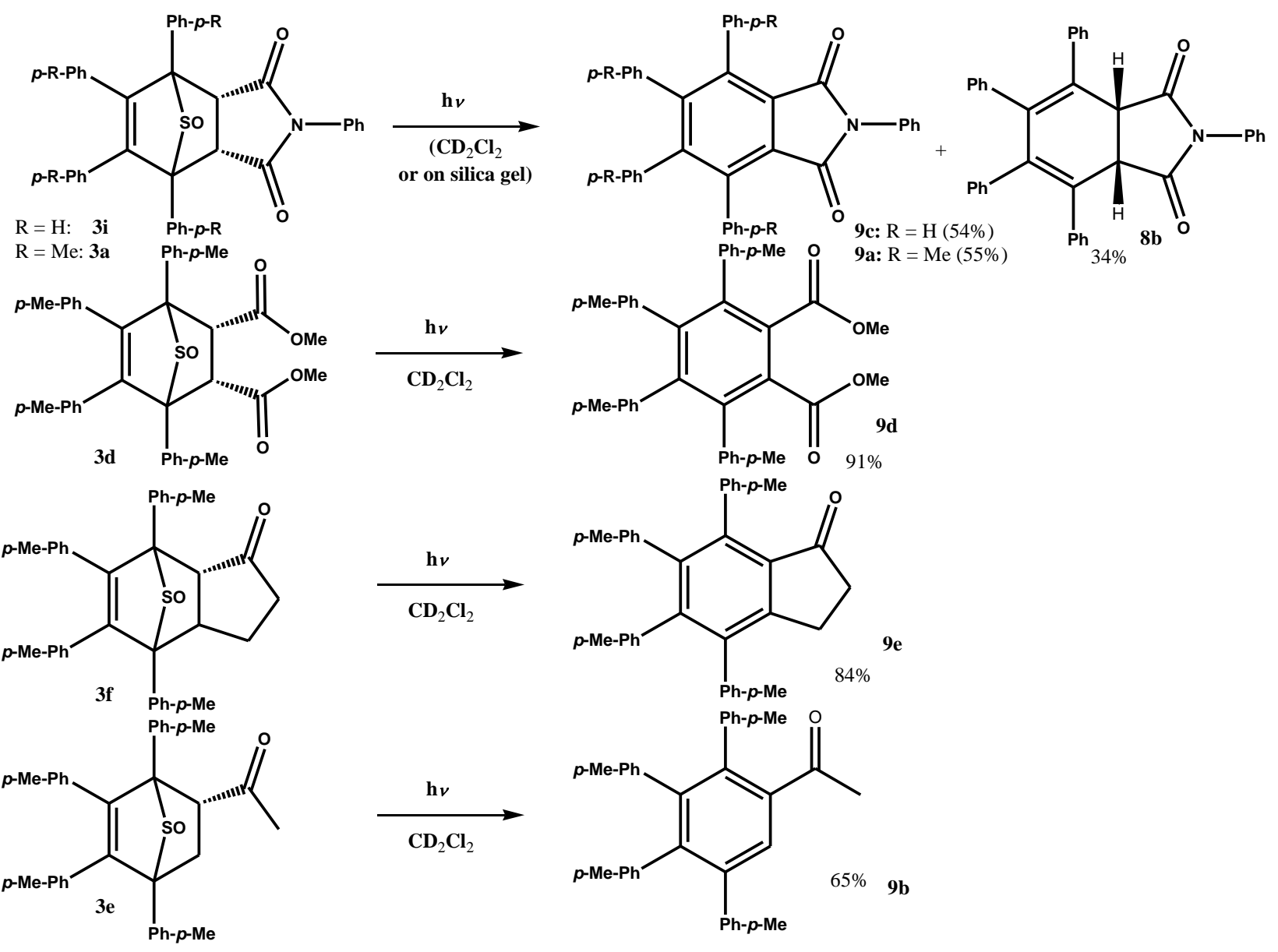

Scheme 7 